\title{
The nowtopia of the riverbank: elder environmental activism.
}

\author{
Abstract \\ Degrowth imaginaries offer alternative ways of envisioning future societies. Those, \\ predominantly working age and working class people, seeking to purposefully enact \\ degrowth in the here and now are termed 'nowtopians'. Based on empirical work \\ undertaken along the River Adur valley in West Sussex, UK, this paper argues that \\ dynamic examples of nowtopian initiatives can develop from alternative and overlooked \\ demographics, such as rural community elders. Explored through a series of interlinking \\ activist narratives, orientated around collective responses to changing riverbank \\ environments, this paper argues that the genesis of this elder activism is a desire to re- \\ assert agency in older age that can be linked to degrowth sensibilities. Contending with \\ the new realities of living under 'austerity localism', many of these elders have \\ undergone a personal, if not political, epiphany and have turned to forms of \\ environmental activism to articulate their agency and demonstrate solidarity with fellow \\ humans across generations. This paper argues that these elder nowtopians champion \\ direct action, conviviality and living well. Ageing and place-connectivity are the \\ motivators which underpin one of the key nowtopian concepts: 'redefining life's \\ purpose'. Reflecting back, projecting forward, but operating in the 'now', these elders \\ helps us to consider a 'politics' of degrowth through grassroots activism along a rural \\ river catchment.
}




\section{Introduction}

Degrowth scholarship is centred upon imaginary thinking. As Petridis et al., (2015:193) state:

'Degrowth is not only a theory. It is an imaginary that already informs, consciously or unconsciously, with precisely this or similar terminology, the imaginary of many collectives that produce on the ground alternatives to the growth economy'.

Attempting to 'decolonise' (Latouche, 2015) entrenched presumptions and visualise other ways of being-in-the-world is central to degrowth sensibilities. The use of the term 'sensibilities' here calls to the ways in which degrowth brings together a panoply of pragmatic and philosophical perspectives, actions and approaches which support a repoliticising of environmentalism against the stupefying narrative of sustainable development (Kallis et al., 2015:9). What connects the alternative cosmologies of degrowth thinkers, whether these are practices of 'sufficiency' (Hall, 2017), of 'reciprocity' (Andreoni and Galmarini, 2013) or of Ubuntu's 'relatedness' (Le Grange, 2012) is a shared imagination that other ways of living life together are, and have been, possible. These ways of thinking and acting challenge us, as academics, as practitioners, as citizens, to imagine a world where prosperity is delinked from consumption; living well is intimately linked with living with less. Degrowth's ambit is radical, liberational, though not prescriptive. Necessarily diverse in scale, orientation and approach, degrowth 
engages directly with imagining alternative ways to sculpt flourishing societies to demonstrate that other forms of collective being-with are possible (Bell, 2016; White and Williams, 2014). These collective, connected responses by people as part of mainstream communities have been termed by Chris Carlsson as 'Nowtopias' and those who engage 'nowtopians' (2008).

'Nowtopians' are framed by D'Alisa et al., (2015) as 'the action' element of the degrowth vocabulary. Alongside Carlsson's ‘tinkerers, inventors and improvisational spirits' (2008:182) squatters, eco-community residents, local volunteers, permaculturalists, land occupiers and many more, those who seek to shape their own autonomy within mainstream culture are deemed nowtopians. D'Alisa et al., argue that a 'degrowth imaginary' (2015:8) underpins nowtopian projects and activities which 'are convivial, (they) involve voluntary work and they are governed and shaped directly by their participants' to support 'a new politics of work' (Carlsson, 2008:3).

However, by focusing on a 'new politics of work' a rich seam of active, progressive nowtopian social activity is effectively overlooked: the retired and the elderly. We suggest that their experiences of environmental degradation and state withdrawal from public services have generated personal and political epiphanies which cannot be easily understood or defined within the existing vocabulary of nowtopianism. Appreciating these elder 'lifeworlds' (Edgar, 2006), wherein political awareness has formed later in life (Guillemot and Price, 2017; Walker, 2010) enables us to consider the importance of experience gained over a lifetime. Moreover, the crucial role of place connectivity in 
shaping identities comes to the fore. Our immersion in landscape is central in shaping our sense of self in relation to the world (Schumacher and Gillingham, 1979; Ingold, 2011). Using the concept of the riverbank as both a physical presence and governance boundary, and as an imaginative presence, enables us to reflect on time, community and humannature connectedness from a degrowth rationale. Degrowth's engagement with environmental politics can only be enriched through insights gained at the scale of the lifeworld; what is happening to our local environments and the community responses enacted by actors who do not easily fit within schematics of 'activist' or 'nowtopian'.

This paper uses empirical research undertaken in three waterside villages in Southern England to argue that elder activism can provide a new set of themes and concerns for nowtopian thinking. Degrowth scholarship could use these experiences of emergent civic environmentalism to expand its appreciation of plural forms of social action. The paper also suggests that the degrowth movement must be careful not to assign nowtopian agency only to the young or physically able, because political awakening can happen at any stage of life. This is particularly the case when the affective support needed in later life reveals the paucity of social welfare systems weakened through decades of neoliberal policy making. In making this argument, the paper suggests that appreciating and recognising gerontocractic activism through an empirically founded immersion into their everyday lifeworlds enriches both degrowth and nowtopian scholarship.

This paper is developed in three sections. The first section expands upon the emergent literature which defines 'nowtopias', to explore its place within degrowth scholarship to 
argue for the need to expand its purview towards mundane, often overlooked, spaces that are mostly populated by an ageing demographic. The following section introduces the empirical fieldwork which challenges the existing depictions of nowtopian communities within the literature. The final section discusses the utility of revisiting the term 'degrowth imaginaries' from the perspective of gerontocratic nowtopian activism to reflect on how ageing and place connectivity can contribute to existing scholarship.

\section{Connecting degrowth and nowtopianism}

'How wonderful can life be? Shouldn't we be trying to find out?' (Carlsson, 2008:252).

Nowtopian scholarship is concerned with 'time and the technosphere' (Carlsson, 2015:182) to capture contemporary examples of activism and community building which occur outside of waged labour relationships and which accord with degrowth sensibilities. As an emergent sub-genre of the degrowth canon, nowtopianism celebrates the range of grassroots, often digitally enabled, pragmatic responses to generating environmentally sensitive ways of being which exist in the everyday. From guerilla gardening in vacant urban spaces and community programmes to teach people to build and maintain bicycles, to the development of biofuel networks to reduce waste and promote skills exchange, Carlsson argues that nowtopian practices represent countercapitalist subcultures (2008:245) often operating within, and parallel to, mainstream culture. These endeavours demonstrate that other, non-monetary, ways of relating with 
each other are possible. 'Human scale' (Max-Neef, 1986) ways of living can penetrate capitalist domains through what David Harvey (1995) terms 'militant particularism.'

Carlsson, in his 2008 book Nowtopia, is the originator of the term. His work focuses on bringing our attention to the ways in which, at least in the United States, subcultures form in new spaces outside of 'workplace and neighborhood' (2008:150). Modern technologies such as the internet and mobile phones enable people to connect in different ways to create new 'social communities' $(2008: 236)$ which aim to make 'practical transformations' which sit firmly within a degrowth platform. Petridis et al., (2015:188) have described this as a 'bottom up' approach to shaping counter-cultural livelihoods.

Nowtopian protagonists are depicted in the literature as responsive, agile and tenacious; they seek to use their agency to shape a better, fairer, world which rejects the atomized, individualizing tendencies of neoliberalism (Carlsson, 2008) and grandstanding utopian ideals. Nowtopian actors and communities take many forms, including: Freetown Christiania in Copenhagen, Denmark; Lammas Ecovillage in Wales; the global Community Supported Agriculture movement (Rioufol and Ravenscroft, 2012; Ravenscroft et al., 2013); the Burning Man festival; and the guerrilla gardening movement (Reynolds, 2014). While each being individual, all of these forms champion alternative approaches to world building in which new forms of neighbourliness are central.

As a result, scholarship which sits within the nowtopian canon is broad and includes enterprises such as community time-banking (McGuirk, 2017) and local currency exchange (Dittmer, 2013), eco-village education and outreach to reduce material consumption (Lockyer, 2017) and gardening as activism (Cattaneo and Gavaldà, 2010; 
Nettle, 2016) as well as a plethora of community practices and traditions (see Paulson, 2017). From this perspective human labour, work, but not just paid work, is presented as worthwhile, fulfilling and necessary. Nowtopianism doesn't offer a manifesto; nor is it a social movement - and in most cases is also not a moniker that these actors would adopt themselves. Instead degrowth scholars recognise that the small scale, self-directed activities which support local community building, environmental care, self-esteem, creativity and social connectedness, amongst innumerable other benefits, work towards the nowtopian vision to unshackle 'work' from capitalist relations and provide a common ground for human expression and interaction.

Given its 'tinkering', decentralised and accessible ethos, much of the nowtopian literature is accessed through online communities and blogs (Justseeds, 2018; The New Commoner, 2018), twitter feeds, Instagram pages (Cyborgmemoirs, 2018) zines (Processed World,2018; ZMagazine 2018) and websites (rabble, 2018). Despite its digital presence, nowtopian views are still manifestly those from the global North. We must be sensitive to degrowth critiques which pinpoint a lack of engagement with actors and communities in the global South (Weiss and Cattaneo, 2017). This paper does not explore this debate, but recognizes that nowtopianism does not sit comfortably with people living in poverty with few, if any, choices facing them. Further, these digital communities appear to reify a trope of nowtopianism as belonging to those who are politically conscious, technically savvy and socially connected. As a result, swathes of actors who are engaged in environmentally focused, community building, activities well within the degrowth imaginary are unwitting excluded from the nowtopia conversation because of 
their low visibility, poor social networking or technological illiteracy. Weiss and Cattaneo's (2017) meta-review of peer reviewed academic publications on degrowth writing between 2006 and 2015 argues that more qualitative empirical work is needed in order to engage with real world examples of degrowth in action. This would enable the degrowth discourse to be promoted within the social sciences as well as using it to gain wider public recognition. This suggests that degrowth scholarship could greatly benefit from more fieldwork based evidence exploring responses to environmental degradation and championing alternative forms of being-in-the-world.

In addressing this gap, the paper focuses on considering nowtopian actions with low visibility from a degrowth perspective. There is a tendency within the literature to identify the nowtopian drive or 'impulse' (Carlsson and Mannning, 2010:930) as that of primarily a class struggle to reclaim agency against the strictures of neoliberalism: 'Nowtopians are a part of the working class with a specific experience of capital, whose struggle, if cognizant of its resistance to capitalism, can feasibly link with other struggles over a common enemy' (ibid). This creates a potential boundary regarding who can 'be' a nowtopian, inasmuch as there is a class politics which precludes universality. There are then, presumptions which underpin nowtopian framings - that nowtopianism is a grassroots initiative of the working class, deliberately pitted against capitalist labour relations. Yet, we contend in this paper that this excludes types of social connectivity which do not sit easily within framings of class - or at least of the 'working class.' As a result, we intend to pursue a more integrated and inclusive perspective on nowtopian activism. 
D'Alisa et al., (2015:32) have described the degrowth imaginary when implemented as the 'reproductive economy of care'. This gets to the heart of nowtopianism: the creating and enabling of forms of living, working and producing together which sit outside of capital exchange and instead generate new commons and new forms of relationality. Instead of the focus of much current degrowth scholarship, on forms of nowtopian community building that are deliberately underpinned by an overtly political rationale, we propose that such intentionality is not inherent to all examples of nowtopias. Rather, we suggest through the empirical fieldwork outlined below that the 'reproductive economy of care' is far more ubiquitous than the existing degrowth literature might at first indicate or seek to allow. Further, we argue that the nowtopians whom we have observed undertaking degrowth practices are those who are often most overlooked in our society, and in conventional nowtopian literature: community elders of more than one class affiliation living in small, often rural, communities. We argue that the 'politics of austerity' experienced throughout the global North has led these community actors to respond to changes in their everyday experience and quality of life; and to reflect on the way that they have hitherto lived their lives. These reflections have caused alliances to emerge, in a responsive, emotive form, leading community members to reassess not just their current actions, but also to re-evaluate the tenets upon which they had previously grounded their lives. The degrowth perspective is thus enriched through a contribution which shows that, 'redefining life's purpose' (Carlsson and Manning, 2010:934) can happen at any time, even towards the end of life. 


\section{Elder environmental activists on the riverbank}

The aim of the empirical research, which took place in 2016, was to explore how rural communities understand and respond to changes in their local water environments. The backdrop to the research was informed by the UK's Localism Act in 2011 (DCLG, 2011) which shifts the onus of responsibility for a range of management issues, including water management such as land drainage and smaller watercourse maintenance, from local authorities to local communities. As a result parish councils (local civic bodies with administrative powers run by elected volunteers many of whom are retired), were abruptly required to take responsibility for quite complex technical and financial decision making on behalf of their constituency. Featherstone et al., (2012) have described this neo-liberal turn as 'austerity localism'; a further stripping back of state intervention and responsibility under the guise of participative governance. Further, localism was

presented as an opportunity for communities to define and strengthen their own resilience to a range of potential contingencies with little or no guidance as to how this might be implemented.

Using water resource management issues as the framing for the research meant that a wide range of respondents with different interests and skills sets could engage with the discussions. The research approach focused on environmental rather than overtly political issues to widen the range of people who would participate. Water resource management issues can mean flood risk prevention, drinking water quality, environmental management, protection and conservation as well as accessing and enjoying local waterscapes. 
The River Adur catchment was selected for the study. Located in the county of West Sussex, adjacent to the South Downs National Park in South East England, it is mainly rural though only 50 or so kilometres from London. The area is populated with small villages and larger market towns with most of the local economy supported by farming, small businesses and tourism generated by visitors to the National Park. The catchment's villages differ from the local towns as they have a higher number of retired residents, aged sixty plus, encompassing a diversity of socio-demographics with a mixed housing stock of both large detached homes and smaller former social housing properties. Many of the respondents interviewed had retired to the villages because of the beautiful countryside.

The study site, just within the tidal stretch of the river midway along the catchment, is comprised of three closely located waterside villages: Steyning, Upper Beeding and Bramber. Survey participants were asked to share with the researchers their experiences of changing water environments within their villages over the past decade, and their responses or actions to these changes. These participants were recruited on the basis that they lived or worked in the villages and had some interest, understanding or role, in local water resources management. Consequently emergency services providers, business owners, parish councillors, farmers, community volunteers, planning officers, householders, property developers, writers and historians were amongst the cohort of participants who were approached and took part in the one-to-one semi-structured interviews. No level of expertise in water resources management was required; simply an 
interest in local water matters past, present and future. Respondents were asked to talk about their local water environments, leading to an open, generative interviewing format, lasting an hour on average. In all thirty seven interviews were conducted over the course of the research.

Interviews were transcribed and subject to thematic analysis. First order analysis categorised the data into groupings such as 'flooding', 'drainage', 'pollution', 'access', 'management' and 'governance'. However, it became clear that what was manifesting through these interviews was more akin to an oral history, as interviewees' own personal journeys were combined with their interest in water management, local history or environmental governance. As the majority of interviewees were retired, and even for those who were not, asking them to consider local water resources led to a reflection on their own life's path. Time and again participants questioned why the public sector services they had come to expect after years of working and paying tax were no longer assured, leading them to question what would happen to them as they aged - given their sense of a lack of community around them.

\section{Creating a meaningful life in a post-work world}

Quite a number of the participants had moved to the area because of the river, nestled as it is within the landscape of the South Downs. Of these, most are retired people for whom the riverbank is also a place of the imagination, where they can contemplate a different life after working life is completed. Other incomers were younger, commuting to work 
away from the villages. They also valued the river, but perhaps more as a signifier of the 'rural idyll' (Mingay, 2017), reflecting a better quality of life for them and their families.

New relocators, the retirees, initially used volunteering in various water resources management capacities as a route to enjoy meaningful activities and build their social networks. Some joined existing local environmental groups, meeting several times a week, either to get involved in the physically hard labour of cutting riverside vegetation or tree planting, and through seasonal citizen observation activities such as bird surveys and river water quality measuring. A large scale one-off activity was in response to degraded local river water quality. In 2015 local anglers and the Ouse and Adur Rivers Trust fund-raised to hire heavy machinery to clear riverbeds and deposit aggregate to help water decontamination and support breeding grounds for spawning fish. Reflecting on the work, several respondents alluded to the need to take direct action, even aligning with those whose perspectives radically differed from their own, because they shared the same ultimate goal, as one of them observed:

"If you get a mobilised, engaged, enthusiastic, driven (Parish Council) chair, the world is your oyster, then you get people that have maybe been doing it for too long, but you just can't find anybody else to take it on....so that community engagement thing again is really interesting, and I reflect back into my own life. I have nothing to do with local politics, but I think I have quite a lot to do with my community."

[local community volunteer co-ordinator, male, working non-resident, late 40s] 
Other examples of nowtopianism include volunteers in one village who spent time researching local drainage maps to identify sources of pollution and who held local meetings to attract support and publicity in order to change local land management practices which, they concluded, were the drivers of the problem. Others volunteered as parish councillors, getting involved in civic administration, often of a very technical nature, particularly around the devolution of riparian drainage responsibilities from the regulatory authority (the Environment Agency) to the local homeowners. Their civic work enabled them to transition out of high status paid jobs and towards useful, but still high status, voluntary work. As observed by one participant: "we are ending up running a kingdom almost here". Another group of newly relocated retirees enjoyed a creative relationship with the riverbank, by joining walking groups or local art initiatives, or by undertaking solitary endeavours such as writing and thinking, using the river as their inspiration.

Talking to these newly retired relocators it was resonant that their move was connected to a determination to shape a meaningful life post work, to enjoy the fruits of working life. Yet more than this was also a wistfulness; of reflecting over a life that has passed. After the headlong rush of work, family, caring, these participants now were re-evaluating what this next stage of their lives might mean for them. Time became the underlying theme behind the research conversations; that the focus changes from working towards longterm goals to appreciating that everyday is to be cherished. More than one respondent emphasised the joy of finally engaging in their passion for nature conservation, in slowing down time that they felt was passing too quickly: 
"I mean, I just do this for, for love, you know. There's no money, no allowances, there's nothing."

[male, retired environmental conservation volunteer, early 70s]

Yet not all of the voluntary activities were supporting health and wellbeing in their myriad forms. For some, volunteering was a necessary response to failing local authorities and a withdrawal of state support. Indeed, as discussed in the next section, volunteering was identified by some interviewees as the only way to protect local habitats.

\section{Resilience in counterpoint to austerity localism}

Many residents told stories about the ways in which their lives had been altered by the impact of flood events. In one case the residents of a country lane, far away from the river but nestled within the chalk downland, explained how over the past five winters their homes had become deluged with water sluicing down the tarmac road from the South Downs to pool at the bottom of the lane, washing onto their front gardens and into their houses. As a result, postal and delivery workers would no longer service the street, the residents' cars were damaged by stones and other debris in the water thrown up by passing traffic, and garden walls and brickwork mortar were showing signs of erosion from water intrusion. Although a downland spring had always trickled down the side of the lane, and was a renowned resource for village children to float home-made paper boats and dandelion faeires, the volume of water had now increased substantially in the autumn and winter. A collective of activists was formed to keep pressure on the local 
council. Comprised of six active older members, representing eighty local residents, who would meet regularly to plan activities, there were another twelve 'sleeper' households who would get involved when they could. The activists collected and submitted photos and engineers' reports showing water billowing along the road, scouring the road surface and making transit difficult for the forty or so households. When asked for their diagnosis of the cause of this recent flooding the activists were clear. They perceived it as a combination of changing land management practices, in terms of crop type and tillage, by the land owner and tenant farmers at the top of the lane, and a withdrawal of local government services leading to the County Council no longer maintaining the highway or the drainage systems in the way that they had been historically. Further, the environmental regulator, the Environment Agency, had also actively withdrawn from managing the drainage maintenance of minor watercourses; something that it historically undertook as a municipal benefit but which legally was the responsibility of every property owner.

As a result the residents perceived that farmers and landowners were causing the soil to become compacted, preventing rain from being absorbed and instead causing it to cascade from the top of the inclined lane. 'Grips' and other small diversion channels that would have traditionally slowed some of the water's progress from the lane and into roadside copses and dips were now no longer being maintained by the municipal Highways Agency. With nowhere to go but straight down, the increased water volume and velocity resulted in a tumult for the residents to manage. With great candour the residents outlined that the discomfort and inconvenience they suffered should not be a 
postcode lottery; they paid their residential Council Tax for highways services and they felt they were being unduly discriminated against:

"We do get quite large chunks of tarmac and stones and things that are washed down...when it does rain hard and the water gushes down it brings all the stones down as well....there's no real champion if you like from the Council who, who really they say they want to help us out but it's only for their political needs there's no money around."

\section{[local resident, newcomer, working, male, early 60s]}

For these citizens, banding together to both clear the drains of leaves when and where they can, attending and petitioning at parish council meetings, fundraising for and commissioning engineers' reports is all part of a grassroots, responsive endeavour which actively challenges the notion that their local environment has to adapt to these imposed exogenous forces. They are adamant that their voices will be heard, but wistful about how long, as campaigners of retirement age, they can keep their activities going:

"Because obviously as people get older they're not, they're less able to, to do these things, aren't they? So you know, that's fine for the next five years but I think after that we'll probably be struggling".

[local resident, late 50s, female, retired]

This connectivity, between austerity localism and the more nuanced impacts it has on older people's lives, is resonant also within another flooding incident. Here, flooding came through groundwater discharge, which is common in river valleys with high water 
tables, leading to the groundwater sitting within saturated soil, close to the land surface. In this instance the water flooded a private house and adjacent business premises owned by the householder. Although rainfall contributes greatly to the amount of water in the soil, the owners felt that the water table had been directly impacted by the rapid and dense housebuilding schemes higher up the river's catchment. With property developers required to provide minimal drainage alleviation in the UK, unlike in other European countries such as Germany where Sustainable Urban Drainage Schemes are legislated, many interviewees - including the householders - cited more roads, more buildings and more hardstanding such as off-road parking, as responsible for the rise in the local water table:

"The [flooding] problem ... wasn't actually caused by the Adur down here. The water just came down slowly through, through the fields; you couldn't really see it but it was below the surface of the grass if you like. You could actually see it coming off the ditch into our garden, you, you could see the flow of it there."

\section{[retired business owner, female, mid 60s]}

: As the householders went onto say:

“... it is so disruptive because once the house gets wet as, as Penny said we were out [having to live elsewhere] for, well it was nine and a half months wasn't it?

They talked through how flooding had awakened them to austerity politics: that when their home flooded they realised there was no-one to help them, no administrative 
structure or service provider to enable them to return to their prior circumstances. Instead, they felt alone and abandoned by the state, wondering what their taxes, their insurance, all their hard work had gone towards. Their response was to join their local flood action group and to invest a large proportion of their retirement savings into adding flood protection cladding to their property - a property they felt would no longer be sellable. One of them commented, with respect to their neighbours who had also experienced flooding, that:

"Anyway they're trying to sell it and they've had three sale agreed signs up and all removed and we believe, certainly the first two were to do with insurance and inability to get insurance".

\section{Activism and community: the creation of gerontocracies}

"Basically everything that you used to rely on is just withering away and if you don't take it over yourselves, you lose it.

\section{[female parish councilor, early 60s, newcomer]}

Time and again the interviewees reinforced that their desire to keep their community together superseded the challenges of relying upon an ageing cohort of local activists. From running local libraries, to guerilla gardening, to keeping hedgerows and roadside verges trimmed, to organizing village fetes and funding local youth spaces, the weight of responsibility lay on village elders who continued to be the most visibly present and online responsive sector of the local community. This activism is clearly in response to 
funding cuts and had generated a local gerontocracy in charge of organising the community and managing allocated funds from local government.

As onerous as the workload appears to be there is a tenaciousness from these respondents who recognise the need to fight for their share of local council monies:

"..so a lot of the things that we have been coming to accept as, as our right, in terms of a community service, are partly being bypassed because the money has to be funded into areas where they (local authority) are legally obliged to spend it....when the counties, the counties and the districts want their cake and eat it, they want to take the money off you." [male, retiree, early 60s, local action group campaigner on land fill pollution]

\section{Discussion: practicing nowtopia on the riverbank}

What is immediately clear from the participants in the study is that they wish to commit their time to what they see as constructive activities that will benefit the wider community as well as themselves. Given the vacuum in managing municipal services created by the impacts of austerity, there is certainly an element of deliberate civic activism within these activities - even political activism to the extent that some of the residents have taken over functions that would, in the past, have been undertaken by the local authority.

So it is in the Adur Valley, where many elders have chosen to deploy their time and expertise in the service of their local communities. For some, this is for the joy of social connectedness; for others a necessary response to the long, slow withdrawal of 
government resources within rural communities. Yet, as we have found, while this may be empowering for some, others have become anxious about the withdrawal of the state and its machinery. Indeed, the data indicate that within the research site many residents feel left behind by changing political and economic climates. Yet the research has also found a vanguard of active, motivated elder 'nowtopians' working together to enact change. Catalysing voluntary community participation as part of a search for new meaning and value is a potentially vibrant element of creating a nowtopia, built on a foundation of action and imagination, combining to ignite a sense of the possible. And the possible, in this context, is centred on empowered agency - older people finding new purpose in supporting the civil commons that promotes resilience to flood, pollution and other environmental impacts in the communities of the Adur Valley.

This idea of regrowth commons goes further, as a reflection of shared values and a collective imagination framed by age and experience. Within these three waterside villages many older residents are recently retired in-migrants. This is significant. Bringing with them a range of skills acquired through their former working, social and cultural lives and a desire to develop new social networks, these nowtopian actors are keen to maximize this stage of their lives by offering their experience and know-how to their new communities. Further, the location is everything. Many of the respondents cherish the South Downs location and their village homes, nestled in the valley. There is something about a riverbank, a water meadow, a footpath along a stream, which conjures images of daydreaming, idling, fanciful thoughts and resolution making. Staring into flowing water evokes a reflectiveness of past, present and future times, a kind of 
multidimensional scrying. As one elder environmental activist so beautifully recalls when asked how his angling, parish council work and environmental conservation interests coalesce in one place:

"Who else in this world sits on a riverbank and watches and sees the water and sees what's going on?"

\section{[angler and local volunteer, male, working, late 50s]}

The motif of water in this analysis of rural nowtopias is key, because the riverbank becomes emblematic of reassurance and continuity against a backdrop of changing environmental and political environments. Ageing thus sits well with our reflection on the significance of riverbanks. Change is perceived as part of life. Something, if not exactly to embrace, certainly to work with rather than against. For many of the respondents their new post-work lives have been shaped by being drawn to living within this downland landscape. One of the central motifs of Carlsson's nowtopia is the importance of defining the self outside of waged labour relationships. The research shows that this is just as important, if not more so, for those at the post-work phase of life.

Landscapes are formative to our identity and sense of self. The nowtopians on the banks of the River Adur are prompted by a collective response to both a changing natural environment and a changing political landscape in which certainty has gone. Reflecting on the data, it is possible to argue that the post-work phase of life has enabled those respondents who might have otherwise have eschewed 'alternative' forms of livelihood addressed within the current nowtopian literature to recognize their potency. In particular, 
these elder nowtopians are well able to observe the paucity of consumer orientated lifestyles and the impact that neoliberal policies have had on local communities and individual lives. For many of these elders, these observations seem to have catalysed a late-onset political awakening.

The data highlight that there is both a closeness and a separation from the lived environment; that working lives separate us from where and how we actually live in community with one another. Jean Luc Nancy (2005) captures this dissonance as a 'strangeness' as we try to close this gap, to react against this estrangement through leaving some kind of material or bodily imprint upon our environment - a responsive mark-making (Ingold, 2010). We can, therefore, see these gerontocratic nowtopias as a visceral form of generative mark making, demanding agency and recognition to enable a temporal 'common being-with the earth' (Mules, 2008: 2009).

Temporality is crucial here. For these elders time is both what gives them agency, as they have skills and experiences to rely upon when shaping their nowtopias, but is also their greatest adversary. The irony is not lost upon the respondents that the young have the time, their whole lives ahead, but perceive it differently, or rather, are caught in the world of paid work which distorts and strictures time: "The younger generation? Not interested, haven't got the time". Similarly, in commenting on rural family lives in which parents commute long distances and children are engaged with a gamut of after-school activities, one community elder observed that: "they don't live here; they just sleep here". 
Can we see these nowtopias as also something 'other'? That these practices of 'redefining life's purpose' (Carlsson, 2008) are a recognition that there is only the 'now' that we can control and influence; that change will occur almost certainly beyond our control. This accords with a pragmatic response to the overwhelming nature of climate change impacts, questioning what is actually feasible in times of financial and political austerity. As one parish councillor sagely noted: “the environment doesn't rank very high for politicians when they're strapped for cash does it?"

Along with time and agency come considerations of legacy; the indefinable 'mark making', to show following generations what are, ultimately, the things of importance. As the municipal structures we have presumed sacrosanct - local government services, our own physical abilities, family connectivity - change, both positively and negatively, what the nowtopian engagement offers is a reclamation of capabilities within a paradigm which seeks to depict elders as economically unproductive, intolerant and hopelessly dated. Nussbaum and Sen's (1993) work brings a focus on degrowth's exploration of conviviality, buen vivir and 'sufficiency'. Respecting, enabling and supporting their '10' capabilities within a nowtopian imaginary highlights the importance of re-evaluating what it is we think, and hope, that we are working towards. The examples drawn from our riverbank elders highlight that agency can, and must, be restated throughout life and that work, once removed from its monetary tethers, can be a source of delight, and regrowth. Considering the different benefits the interviewees gained from community engagement - physical fitness, mental stimulation, social connectivity, conviviality and a reinvigorated sense of themselves as part of a greater collective - we can say that these 
gerontocratic nowtopians highlight how the degrowth agenda can provide different forms of physical, mental and social wellbeing.

\section{Conclusion}

Reflecting upon gerontocratic nowtopias reveals that once freed from social hierarchies the 'post work' world recasts work, labour, as a productive, life-affirming activity. For many of those interviewed this is the defining, liberating, value in the different environmental activist roles that they inhabit. Environmental activism at this 'third age' of life is connected to this search, desire and need for conviviality and regrowth. This work is joyous; claiming an identity that was, perhaps, left dormant during the years of waged labour (or maybe was never previously claimed). Instead, theirs is a demand to celebrate and enjoy health, nature, the outdoors and physical contact. Rather than hollow consumption, these new individual and collective endeavours are concerned with making and improving - all helping to create new identities and collaborations that sit outside of monetary and consumerist goals.

The empirical research offered here suggests that these elder environmental activists are part of a nowtopian vanguard. They contribute to self-producing nowtopias which are appearing in different sites with different foci. Unlike eco-communities or peripatetic gatherings such as Burning Man or NoWhere, there are a plethora of ordinary, pedestrian, low visibility nowtopian practices burgeoning in unrecognized corners. As we argue, we must be careful to be attendant to them or we risk failing to recognize the unique contribution that these elder nowtopians make, both to their communities and as a cohort 
from which degrowth researchers can learn. More empirical research is therefore needed on the subject of regrowth, to extend current degrowth scholarship and to find examples of elder nowtopian enclaves in other countries and contexts.

Elders in this research have highlighted a pragmatism that comes with age; that having faced the retreat of the state and with a decline in social networks, these resourceful, imaginative elders have combined approaches which integrate strategies of social insurance along with positive endeavours to make their immediate landscapes and lifeworlds improved for all civic actors. Imagination and agency in ageing are intimately linked, as these older activists recall the riverbanks of their youth, of their cultural imaginary and of their aspirations of now and in the future. Reflecting on the importance of what makes a good life has led to a range of social, physical, emotional and political encounters with others and their surrounding environment. Connected to this is a spontaneous confirmation of degrowth sensibilities; that without strong connected, empowered communities, a healthy environment and our own physical and emotional health our lives are denuded by a morbid fixation on accumulation at all costs.

Returning to Weiss and Cattaneo's (2017) meta-review of peer reviewed academic publications on degrowth, the research that underpins this paper suggests that the degrowth discourse would greatly benefit from more qualitative empirical work which engages with real world examples of divergent forms of nowtopian activities. Moreover, our results suggest that the discourse around nowtopias would be enriched through an 
appreciation of the contribution that elder rural environmental, political and civic actors make to their communities, often unrecognized and undocumented.

Within this paper, and within the nowtopian ouvre itself, we have come to understand the importance that making a useful contribution to local communities and neighbourhoods means for creating value and self-worth for individuals. For our respondents, the riverbank has come to represent the 'liquid modernity' that Bauman (2000) heralds as the apogee of late capitalism, in which relationships, self-identity and sense of place are all in motion as the state retracts and capital actively claims this space. The riverbank is both culturally fixed in our imagination, and exists as a physical, political boundary; but our research has shown it too as a mutable concept. Our elder environmental activists experience the riverbank as a physical entity through their riparian tree planting and riverine biodiversity surveys, and as a representational construct - as austerity politics and changing social relationships bring the riverbank to them as they both experience and respond to non-fluvial flooding. Emergent gerontocratic led nowtopias respond to these challenges by seizing the now, affirming life and collectively engaging in exploring and demonstrating that degrowth thinking can learn from the quiet activists pursuing their nowtopian practices on the banks of the River Adur.

\section{References}

Andreoni V and Galmarini S (2013) On the increase of social capital in degrowth economy. Procedia-Social and Behavioral Sciences 72:64-72.

Baumann Z (2000) Liquid modernity. Cambridge: Polity. 
Bell K (2016) Green economy or living well? Assessing divergent paradigms for equitable eco-social transition in South Korea and Bolivia. Journal of Political Ecology 23:71-92.

Carlsson C (2008) Nowtopia: How Private Programmers, Outlaw Bicyclists and Vacant Lot Gardeners Are Inventing the Future Today! Oakland: AK Press.

Carlsson C (2015) Nowtopians. In: D'Alisa G, Demaria F and Kallis G (eds) Degrowth: $a$ vocabulary for a new era. Abingdon: Routledge, pp. 182-184.

Carlsson C and Manning F (2010) Nowtopia: strategic exodus? Antipode, 42(4): 924-953.

Cattaneo C. and Gavaldà M (2010) The experience of rurban squats in Collserola, Barcelona: what kind of degrowth? Journal of Cleaner Production 18(6): 581-589.

Cyborg memoirs (2018) Available at: http://www.cyborgmemoirs.com/ (accessed on 7 September 2018).

D'Alisa G, Demaria F and Kallis G (eds) (2015) Degrowth: a vocabulary for a new era. Abingdon: Routledge.

Department for Communities and Local Government (2011). A plain English guide to the Localism Act. London: HMSO.

Dittmer K (2013) Local currencies for purposive degrowth? A quality check of some proposals for changing money-as-usual. Journal of Cleaner Production 54:3-13.

Edgar A (2006) Habermas: The key concepts. Abingdon: Routledge. 
Featherstone D, Ince A, Mackinnon D, Strauss K and Cumbers A (2012) Progressive localism and the construction of political alternatives. Transactions of the Institute of British Geographers 37(2):177-182.

Guillemot J and Price D (2017) Politicisation in later life: experience and motivations of older people participating in a protest for the first time. Contemporary Social Science 12 $(1-2): 52-67$.

Hall A (2017) Neo-monastics in North Carolina, de-growth and a theology of enough. Journal of Political Ecology 24(1): 543-565.

Harvey D (1995) Militant particularism and global ambition: the conceptual politics of place, space and environment in the work of Raymond Williams. Social Text 42: 69-98.

Ingold T (2010) The textuality of making. Cambridge Journal of Economics 34: 91-102.

Ingold T (2011) Being alive: Essays on movement, knowledge and description. London: Taylor \& Francis.

Justseeds (2018) About who we are. Available at https://justseeds.org/about/\#who-we-are (accessed 7 September 2018).

Kallis G, Demaria F and D'Alisa G (2015). Introduction: degrowth. In D'Alisa G, Demaria F and Kallis G (eds) Degrowth: a vocabulary for a new era. Abingdon: Routledge.

Latouche S (2015) Imaginary, decolonisation of. London: Routledge.

Le Grange L (2012) Ubuntu, ukama and the healing of nature, self and society. Educational philosophy and theory 44 (2):56-67. 
Lockyer J (2017) Community, commons, and degrowth at Dancing Rabbit Ecovillage. Journal of Political Ecology 24(1): 519-542.

Max-Neef M (1986) Human scale economics: the challenges ahead. The living economy: a new economics in the making. Abingdon: Routledge and Kegan Paul.

McGuirk E (2017) Timebanking in New Zealand as a prefigurative strategy within a wider degrowth movement Degrowth, culture and power. Journal of Political Ecology 24(1): 595-609.

Mingay GE (2017) The rural idyll. Abingdon: Routledge.

Mules W (2008) Open country: towards a material environmental aesthetics. Continuит: Journal of Media \& Cultural Studies. 22(2): 201-212.

Nancy JL (2005) The ground of the image. Fordham University Press: New York.

Nettle C (2016) Community gardening as social action. Abingdon: Routledge.

Nussbaum M and Sen A (1993) The quality of life. Oxford: Oxford University Press.

Paulson S (2017) Degrowth: culture, power and change. Journal of Political Ecology, 24(1): 425-448.

Petridis P, Muraca B and Kallis G (2015) Degrowth: between a scientific concept and a slogan for a social movement. In: Martinez-Alier J and Muradian R (eds) Handbook of ecological economics. Cheltenham: Edward Elgar.

Processed World (2018). Available at:

http://www.processedworld.com/History/history.html (accessed 7 September 2018). 
Rabble (2018). Available at: http://www.rabble.ca/ (accessed 7 September 2018).

Ravenscroft N, Moore N, Welch E and Hanney R (2013) Beyond agriculture: the counter-hegemony of community farming. Agriculture and Human Values 30(4): 629639.

Reynolds R (2014) On guerrilla gardening: A handbook for gardening without boundaries. London: Bloomsbury Publishing.

Rioufol V. and Ravenscroft N (eds) (2012) Access to land for community connected farming. Seven case studies from the UK, Germany, Romania, France, Lithuania and Italy. Paris and Brussels: Terre de liens and Forum Synergies.

Schumacher E and Gillingham P (1979) Good work. New York: Harper \& Row.

The New Commoner (2018). Available at: http://commonerslink.blogspot.com/ (accessed 7 September 2018).

Walker A (2010) Aging and politics: An international perspective. In: Binstock R, George L, Cutler S, Hendricks J and Schulz J (eds) Handbook of aging and the social sciences (6). Cambridge, MA: Academic Press:pp: 339-359.

Weiss M and Cattaneo C (2017) Degrowth-taking stock and reviewing an emerging academic paradigm. Ecological Economics 137: 220-230.

White R and Williams C (2014). Anarchist economic practices in a 'capitalist' society: Some implications for organisation and the future of work. Ephermera: theory and politics in organization 14(4): 947-971. 
Z communications (2018). Available at: https://zcomm.org/ (accessed 7 September 2018). 